\title{
Imperialism and the Relation between Industrial and Agrarian Countries
}

The problem of external markets for industrial products is even more deeply rooted in capitalist commodity production. According to Kautsky, capitalism is constantly in need of new markets to swallow the increasing amount of commodities produced by the industrially developed countries. Capitalism has a permanent tendency towards overproduction. Overproduction - or rather underconsumption - is the basis of the relation between the industrial and the agrarian countries, which is an essential part of Kautsky's thinking on modern capitalism and his theory of imperialism and ultra-imperialism.

The reasons behind the conception of general overproduction are not altogether clear: why cannot all industrial commodities be absorbed by the consumers of the industrial countries? In this sense, Kautsky seemed to be sharing a conception widely accepted by the Marxists of the Second International. On the most abstract level, the problem of overproduction seems to be a result of the very nature of capitalism as the production of surplus value.

In her Accumulation of Capital of 1913, Rosa Luxemburg ${ }^{1}$ formulated the problem facing the accumulation of capital in a most pronounced manner: the accumulation of capital faces the principle difficulty of realising its surplus product. According to Luxemburg, the continuous accumulation of capital would require a continuous and increasing demand for commodities. And this demand cannot be satisfied within a capitalist economy. As the starting point of her analysis of the conditions of the accumulation of capital, Luxemburg takes the relation between the two departments of production in capitalism as formulated in the reproduction schemes of the second volume of Marx's Capital. Maintaining the right proportion between the two departments of production - Department I producing the means of production and Department II producing the provisions or consumer goods - is as such a permanent problem in capitalism, because there is no predetermined plan for maintaining the right proportion. In principle, it is still possible for accumulation to continue as long as the right proportion is maintained, and no necessary economic collapse can be deduced from the relative development of these two departments of production; still, there is a permanent problem of effective demand in capitalism:

1 Luxemburg 1963. 
It does not follow, however, that so long as both these conditions are observed, accumulation in both departments is bound, as Marx's diagram makes it appear, to go on automatically year after year. The conditions of accumulation we have enumerated are no more than those without which there can be no accumulation. There may even be a desire to accumulate in both departments, yet the desire to accumulate plus the technical prerequisites of accumulation is not enough in a capitalist economy of commodity production. A further condition is required to ensure that accumulation can in fact proceed and production expand: The effective demand for commodities must also increase. Where is this continually increasing demand to come from, which in Marx's diagram forms the basis of reproduction on an ever increasing scale? ${ }^{2}$

According to Luxemburg, this increasing demand can result from the consumption of neither the capitalists nor the workers. A necessary and obvious precondition for accumulation is precisely that at least some of the commodities representing surplus value are not consumed by the capitalists, but are instead accumulated. Workers cannot possibly absorb these commodities either, because the purpose of capitalism is not to increase the demands and needs of the wage workers. Even though Luxemburg did not explicitly refer to the conception of the wage worker as being principally an underconsumer while producing a surplus value, her discussion of the problem in fact led to the acceptance of this premise.

The conclusion drawn from the discussion is, nevertheless, that the realisation of surplus value is altogether impossible within a pure capitalist economy: 'Realisation of the surplus value outside the only two existing classes of society appears as indispensable as it looks impossible. The accumulation of capital has been caught in a vicious circle. ${ }^{3}$ And if the commodities representing surplus value cannot be realised within the capitalist economy, the only alternative left is that - if they are to be realised at all - they must be realised outside it:

Seeing that we cannot discover within capitalist society any buyers whatever for the commodities in which the accumulated part of the surplus value is embodied, only one thing is left: foreign trade. ${ }^{4}$

2 Luxemburg 1963, pp. 131-2.

3 Luxemburg 1963, p. 165.

4 Luxemburg 1963, pp. 135-6. 
But not even foreign trade is the final solution to the problem, since foreign trade cannot simply be directed at other capitalist countries, which also face the same problem of lacking demand. The only possible extra demand for commodities, then, must come from a non-capitalist economy and non-capitalist areas and countries.

It requires as its prime condition ... that there should be strata of buyers outside capitalist society ... The decisive fact is that the surplus value cannot be realised by sale either to workers or to capitalists, but only if it is sold to such social organisations or strata whose own mode of production is not capitalistic. ${ }^{5}$

Thus the accumulation of capital constantly requires the existence of either non-capitalist societies or other non-capitalist social strata. So long as there are non-capitalist markets for the commodities produced in capitalism, accumulation can proceed. Once capitalist production has been established in all the remaining areas and fields of production, accumulation must come to an end, and the final collapse of capitalism will result:

As soon as this final result [the establishment of capitalist production in all the countries of the world] is achieved - in theory, of course, because it can never actually happen - accumulation must come to a stop. The realisation and capitalisation of surplus value becomes impossible to accomplish ... For capital, the standstill of accumulation means that the development of the productive forces is arrested, and the collapse of capitalism follows inevitably, as an objective historical necessity. This is the reason for the contradictory behaviour of capitalism in the final stage of its historical career: imperialism. ${ }^{6}$

Imperialism is the necessary outcome of the problems facing the accumulation of capital, and Luxemburg associated imperialism with all the features later to become familiar in the theories of imperialism of both Kautsky and Lenin: export of capital in the form of international loans, protective tariffs, increasing armaments and militarism, colonial policy, annexation of colonies by the major capitalist states. In earlier capitalism, 'peace, property and equality' prevail - at least in principle. In imperialism, they are superseded by other principles:

5 Luxemburg 1963, pp. 351-2.

6 Luxemburg 1963, p. 417. 
Its predominant methods are colonial policy, an international loan system - a policy of spheres of interest - and war. Force, fraud, oppression, looting are openly displayed without any attempt at concealment, and it requires an effort to discover within this tangle of political violence and contests of power the stern laws of the economic process. ${ }^{7}$

Kautsky's analysis of the necessary conditions for the accumulation of capital resembled that of Luxemburg's in many respects. ${ }^{8}$ It may be claimed that, according to Kautsky too, the wage workers are always 'overproducers' because they are producing a surplus value and surplus product. There cannot possibly be an effective demand for the surplus product by the wage workers. Furthermore, the luxury consumption of the capitalists cannot satisfy the necessary extra demand. The wage workers are by definition thus overproducers and underconsumers. As a result, overproduction is a permanent curse of capitalism:
Along with the periodical crises and their permanent manifestations, along with the recurring periods of overproduction and [the accompa- nying] loss of wealth and waste of force, there develops chronic overpro- duction and waste of energy. ${ }^{9}$

Markets expand much more slowly than production. Hence, it is impossible for capitalism to develop its productive forces maximally: The intervals (periods) of prosperity become ever shorter; the length of the crises ever longer (especially in industrial countries like Britain and France). ${ }^{10}$

In more concrete terms, overproduction is explained by the limitless need for the accumulation of capital and the permanent revolution in the means of production. Since production increases much faster than the number of employed wage workers, it becomes more and more difficult for the capitalists to realise their products on the home market:

$7 \quad$ Luxemburg 1963, p. $45^{2}$.

8 Kautsky actually formulated the dilemma of capitalist accumulation and the relation between industrial and agrarian production before Luxemburg's Accumulation of Capital (see Kautsky 1911b [1901]). It is not known whether Luxemburg's analysis was directly influenced by Kautsky. At least one can assume that the idea was prevalent among the Marxists at that time.

9 Kautsky 1910b, pp. 81-2 (translation modified BL).

10 Kautsky 1910 , pp. $84-5$. 
Furthermore, it is not only the surplus withheld by the capitalist that the growing productivity of labor increases; it also increases the quantity of goods that are thrown upon the market. Along with the exploitation of labor grows the competition among capitalists, which becomes a bitter contest of each against all. ${ }^{11}$

The rapid growth of production and the accumulation of capital in industry are made possible by the development of the modern loan system and the constant supply of free workers on the labour market. There do not seem to be any natural limits to the increase of production.

Even in Kautsky's analysis of capitalism, there is the permanent danger that the proportional relations between the different sectors of production will be disturbed. The relation between the sectors producing the means of production and the means of consumption is especially important. If the right relation is not maintained, there will be serious disturbances in the market. The problem is that the proportional relations are constantly changing due to improvements in the technical and social relations of production. Equilibrium is achieved only through continuous disturbances and changes in prices and volumes of production. ${ }^{12}$

According to Kautsky, there is, however, an even more serious problem in capitalism connected with the establishment of the right proportional relations between the industrial and agrarian products and sectors. Whereas a non-capitalist mode of production is a necessary precondition for the realisation of the surplus value in Luxemburg's conception, there is in Kautsky's analysis a further difficulty connected with the relation between agrarian and industrial production due to differences in the rate of accumulation in these departments. The expansion of industrial production is always possible. Agricultural production is, however, always faced with natural limits - even in its capitalistic form. ${ }^{13}$ There are still other reasons why it cannot expand at the same rate as industry:

The proportionality between industry and agriculture is necessary under any circumstances, but it is always in danger of being violated, first by migration from the countryside to the cities, which deprives agriculture of labour-power in order to supply it to industry, and, secondly, through the

\footnotetext{
11 Kautsky 1910b, p. 70.

12 Kautsky 2011d, p. 759.

13 Kautsky 2011d, p. 764.
} 
development of knowledge and technique in the cities, by means of which the productivity of industry is easily increased. Industrial production also has the tendency to develop more rapidly than agricultural production, because the number of producers and their average productivity grows more quickly in the former than in the latter. ${ }^{14}$

Industrial production is forced to accumulate and find an ever-increasing demand for its products:

The individual capitalist must now constantly increase his production under all circumstances, and, if domestic demand does not naturally grow in the same proportion, then he must employ all the forces at his disposal to enlarge that demand artificially and to broaden the market. The intensity of industrial competition results from the fact that the drive and the possibility to accumulate capital and increase production are far greater in industry than in agriculture. This fact, resulting from the differences between industry and agriculture, in turn becomes one of the most powerful factors causing the distinction between them to grow..$^{15}$

On the other hand, agricultural production is - in a rather trivial sense - a necessary basis for all economic enterprise as we cannot go on living for a single moment without the products of agriculture. If industrial production is to increase continuously, an increase in agricultural production and population is also demanded. The agricultural sector must produce the raw materials and the foodstuffs consumed by industry and the industrial wage workers on an ever larger scale. But even more importantly, it must also be ready to buy the surplus produce of industry which is not consumed by the industrially active population. ${ }^{16}$

Kautsky's main problem is, consequently, how to establish the right balance between agriculture and industry if the accumulation of capital is much faster in industry than in agriculture. The solution is the constant expansion of the agrarian areas and regions in the capitalist market:

Capitalist accumulation in industry can only proceed unhindered and develop freely if the agricultural regions it serves as supplier and buyer

\footnotetext{
$14 \quad$ Kautsky 2011d, p. 762.

15 Kautsky 2011d, p. 766.

16 Kautsky 2011d, p. 767.
} 
expand constantly, which requires a constant extension and improvement of the means of communication. ${ }^{17}$

If the agrarian areas do not constantly expand, there will be an oversupply of industrial products and an overdemand for agrarian products. As a consequence, capital accumulation will be seriously hindered and disturbed. Capitalism has tried to solve the problem by imperialism or colonial policy.

The expansion of the market and the resources of raw materials was possible for Britain with a policy of free trade so long as it was the main industrial country in the world. As soon as other European countries developed their capitalist production and introduced protective tariffs to be able to compete with Britain, an international system of restrictive tariffs - and imperialism was born. ${ }^{18}$

The main determinant of imperialism is thus the contradictory relation between the industrial and the agrarian countries, as summarised by Kautsky in his booklet National State, Imperialist State and Confederation [Nationalstaat, imperialistischer Staat und Staatenbund]. In the same pamphlet - later to become famous as a polemical target of Lenin's Imperialism, the Highest Stage of Capitalism - Kautsky referred to his article Imperialism [Der Imperialismus] published in Die Neue Zeit in 1913-14 as the best presentation of his conception of imperialism. He defined the concept of imperialism as follows:

First of all, we must be clear about what we understand by imperialism. This word is used all the time today, but the more people talk about it and discuss it, the more indefinite it becomes, which of course makes understanding very difficult. By now, the meaning of the word imperialism has expanded so far that all the manifestations of modern capitalism are included in it - cartels, protective tariffs, the domination of finance, as well as colonial policy. In that sense, naturally, imperialism is a vital necessity for capitalism. But that knowledge is just the flattest tautology; all it says is that capitalism cannot exist without capitalism. If we take the word not in that general sense, but in its historical determination, as it originated in England, then it signifies only a particular kind of political endeavour, caused, to be sure, by modern capitalism, but by no means coincident with it. ${ }^{19}$

\footnotetext{
17 Ibid.

18 Kautsky 2011d, pp. 767-71.

19 Kautsky 2011d, p. 757.
} 
Imperialism is consequently not to be understood as being synonymous with modern capitalism in general, but as a specific form of capitalist rule which is, by all means, caused by the economic development of capitalism but is not identical to it. Imperialism is a necessary companion of capitalism - if the modern conditions are taken as given:

Imperialism is a product of highly developed industrial capitalism. It consists of the drive of every industrial capitalist nation to conquer and annex an ever-greater agrarian zone, with no regard to what nations live there. ${ }^{20}$

However, Kautsky firmly believed that imperialism as a method of guaranteeing high profits is doomed to fail in the end; imperialistic policies based on the export of capital and protective tariffs cannot be continued eternally. There is a natural limit to the further development of imperialism. As soon as all the agrarian areas have been divided among the industrial nations, the expansion of imperialism comes to a natural end, and the only way open for further development is an open trade war:

Capital and labour grow at home. The number of consuming industrial countries increases, whereas the number of agricultural countries decreases. In as far as these are still free, they will soon be completely divided up, and then there is only one way for the monopolised territory to further expand: this is no longer the battle between the industrial state and the agricultural state, but the bloody battle between the great industrial states, i.e. world war. ${ }^{21}$

The final result of the analysis proves that there are thus only two alternatives facing capitalism and imperialism: socialism or world war. World war is just one alternative to the system of world trade [Welthandelssystem] that is rapidly heading towards collapse; the other is socialist society. ${ }^{22}$

20 Ibid. Luxemburg's characterisation of imperialism comes close to Kautsky's definition: 'Imperialism is the political expression of the accumulation of capital in its competitive struggle for what remains still open of the non-capitalist environment' (Luxemburg 1963, p. 446).

21 Kautsky 1911b, p. 94.

22 Ibid. 